\title{
Desulfurobacterium thermolithotrophum gen. nov., sp. nov., a novel autotrophic, sulphur-reducing bacterium isolated from a deep-sea hydrothermal vent
}

\author{
S. L'Haridon, ${ }^{1}$ V. Cilia, ${ }^{1}$ P. Messner, ${ }^{2}$ G. Raguénès, ${ }^{3}$ A. Gambacorta, ${ }^{4}$ \\ U. B. Sleytr, ${ }^{2}$ D. Prieur ${ }^{1,5}$ and C. Jeanthon ${ }^{1}$
}

\author{
Author for correspondence: C. Jeanthon. Tel: +332982923 09. Fax: + 33298292324 . \\ e-mail: jeanthon@sb-roscoff.fr
}

\author{
Station Biologique, \\ UPR9042, Centre National \\ de la Recherche \\ Scientifique and Université \\ Pierre et Marie Curie, Place \\ Georges-Teissier, 29680 \\ Roscoff, France \\ 2 Zentrum für \\ Ultrastrukturforschung \\ und Ludwig Boltzmann- \\ Institut für Molekulare \\ Nanotechnologie, \\ Universität für \\ Bodenkultur, 1180 Vienna, \\ Austria \\ 3 Laboratoire de \\ Caractérisation des Micro- \\ organismes Marins, Centre \\ IFREMER de Brest, 29280 \\ Plouzané, France \\ ${ }^{4}$ Istituto per la Chimica di \\ Molecole di Interesse \\ Biologico, Via Toiano 6, \\ 80072 Arco Felice (Naples), \\ Italy \\ 5 Université de Bretagne \\ Occidentale, UFR des \\ Sciences et Techniques, 6 \\ avenue Victor Le Gorgeu, \\ 29285 Brest cedex, France
}

\begin{abstract}
A thermophilic, anaerobic, strictly autotrophic, sulphur-reducing bacterium, designated BSA $^{\top}$ ( $T$ = type strain), was isolated from a deep-sea hydrothermal chimney sample collected at the mid-Atlantic ridge. Gram-negative cells occurred singly or in pairs as small highly motile rods. Spores were not observed. The temperature range for growth was 40 to $75^{\circ} \mathrm{C}$, with an optimum at $70{ }^{\circ} \mathrm{C}$. The $\mathrm{pH}$ range for growth at $70^{\circ} \mathrm{C}$ was from 4.4 to 7.5 , with an optimum around 6.0. The sea salt concentration range for growth was $15-70 \mathrm{~g} \mathrm{I}^{-1}$ with an optimum at $35 \mathrm{~g} \mathrm{I}^{-1}$. Elemental sulphur, thiosulphate and sulphite were reduced to hydrogen sulphide. Sulphate and cystine were not reduced. The G+C content of the genomic DNA was $35 \mathrm{~mol} \%$. Phylogenetic analyses of the 165 rRNA gene indicated that the strain was a member of the domain Bacteria and formed a branch that was almost equidistant from members of the orders Aquificales and Thermotogales. The new organism possesses phenotypic and phylogenetic traits that do not allow its classification as a member of any previously described genus; therefore, it is proposed that this isolate should be described as a member of a novel species of a new genus, Desulfurobacterium gen. nov., of which Desulfurobacterium thermolithotrophum sp. nov. is the type species. The type strain is BSA' (= DSM 11699').
\end{abstract}

Keywords: deep-sea hydrothermal vents, thermophiles, Bacteria, Desulfurobacterium, Desulfurobacterium thermolithotrophum

\section{INTRODUCTION}

Most micro-organisms known to thrive in the hottest parts of the deep-sea hydrothermal vent ecosystem are chemolithoautotrophic and chemo-organoheterotrophic anaerobes that fall into the domain Archaea (Prieur et al., 1995; Stetter, 1996). They include hyperthermophilic methanogens, sulphur metabolizers and sulphate reducers. These organisms are not restricted to deep-sea vents, as members of the genera

Abbreviations: DEPT, distortionless enhancement by polarization transfer; FAME, fatty acid methyl ester.

The EMBL accession number for the sequence reported in this paper is AJ001049.
Methanopyrus, Archaeoglobus, Pyrococcus and Thermococcus also occur in shallow marine hydrothermal systems, offshore and/or continental oil reservoirs (Kurr et al., 1991; Stetter et al., 1993; L'Haridon et al., 1995).

Within the domain Bacteria, the majority of marine, thermophilic micro-organisms described within the past decade have been isolated from shallow marine hot springs. They include thermophilic and hyperthermophilic aerobic species, such as Thermus thermophilus, Rhodothermus marinus, Aquifex pyrophilus (Alfredsson et al., 1988; Huber et al., 1992; Manaia et al., 1994), and anaerobic species of the order Thermotogales (Huber \& Stetter, 1992). From deep-sea vents, the only anaerobic, heterotrophic, sulphur- 
reducing strains that have been isolated belong to the genus Thermotoga (Marteinsson et al., 1997) and a new species of the genus Thermosipho (Antoine et al., 1997). Because the solubility of oxygen is low in hydrothermal environments, microbiologists have been mainly interested in the study of anaerobic organisms. However, the only other thermophilic bacteria isolated so far from depth are aerobic, heterotrophic strains assigned to the genera Thermus and Bacillus (Marteinsson et al., 1995, 1996). The abundance and distribution of thermophilic microorganisms in deep-sea hydrothermal vent chimneys were recently assessed by a combination of traditional culture-based enrichments of strictly anaerobic thermophiles and whole-cell hybridization of extracted cells with domain- and kingdom-specific fluorescent oligonucleotide probes based on 16S rRNA (Harmsen et al., 1997a). Surprisingly, most of the samples contained equivalent numbers of cells from both domains, and at least four different morphotypes of bacteria could be distinguished. One of the observed morphotypes corresponded to small rod-shaped anaerobic chemolithoautotrophic sulphur reducers (Harmsen et al., 1997a).

In this paper, we describe the isolation and the properties of this novel marine thermophilic organism (strain $\mathrm{BSA}^{\mathrm{T}}$ ) and show that it differs sufficiently from any previously described taxon to place it in a new genus. The name proposed is Desulfurobacterium thermolithotrophum gen. nov., sp. nov.

\section{METHODS}

Reference strains. Aquifex pyrophilus DSM 6858 $\mathrm{Kol}^{\mathrm{T}} \mathrm{a}^{\mathrm{T}}$ ), Hydrogenobacter thermophilus DSM $6543^{\mathrm{T}}$ (TK$\left.6^{\mathrm{T}}\right)$, Calderobacterium hydrogenophilum DSM $2913^{\mathrm{T}}(=\mathrm{Z}$ $\left.829^{\mathrm{T}}\right)$, Thermotoga maritima DSM $3109^{\mathrm{T}}\left(=\mathrm{MSB} 8^{\mathrm{T}}\right)$ and Fervidobacterium nodosum DSM 5306 ${ }^{\mathrm{T}}\left(=\mathrm{Rt} 17-\mathrm{B} 1^{\mathrm{T}}\right)$ were obtained from the DSMZ-Deutsche Sammlung von Mikroorganismen und Zellkulturen (Braunschweig, Germany).

Collection of chimney samples. Beehive structures were collected in November and December 1995 from the Snake Pit vent field $\left(23^{\circ} 22^{\prime} 118^{\prime \prime} \mathrm{N}, 44^{\circ} 56^{\prime} 984^{\prime \prime} \mathrm{W}\right)$ on the midAtlantic ridge at a depth of $3500 \mathrm{~m}$ during the Microsmoke cruise (Harmsen et al., 1997a). Using the port manipulator of the submersible Nautile, these chimneys were placed in the submersible insulated basket for the trip to the surface. Once they were transferred on board, subsampling across the sulphide structures was conducted as aseptically as possible. Chimney subsamples were transferred to $50 \mathrm{ml}$ glass vials and flooded with a sterile solution of $3 \%(\mathrm{w} / \mathrm{v})$ sea salts (Sigma). The vials were then closed tightly with butyl rubber stoppers (Bellco), pressurized with $\mathrm{N}_{2}(100 \mathrm{kPa})$, reduced with sodium sulphide when required and stored at $4{ }^{\circ} \mathrm{C}$ until processing.

Enrichment cultures and purification. Chimney subsamples were used to inoculate medium ASR (see below). Enrichments were performed anaerobically in $50 \mathrm{ml}$ vials according to Balch \& Wolfe (1976) and incubated at $65^{\circ} \mathrm{C}$ for 2 or $3 \mathrm{~d}$. Positive enrichments were subcultured and purified by streaking onto ASR medium that was supplemented with thiosulphate $(20 \mathrm{mM})$ and polysulphides and solidified with
$0.7 \%(\mathrm{w} / \mathrm{v})$ Phytagel (a gellan gum from Sigma). Plates were incubated in anaerobic jars at $65^{\circ} \mathrm{C}$ for $3 \mathrm{~d}$ under a $\mathrm{H}_{2}-\mathrm{CO}_{2}$ atmosphere $(80: 20 ; 200 \mathrm{kPa})$.

Culture medium and conditions. The isolate $\mathrm{BSA}^{\mathrm{T}}$ was routinely grown in medium ASR, which contained per litre of distilled water: $30 \mathrm{~g}$ sea salts, $1 \mathrm{~g} \mathrm{NH}_{4} \mathrm{Cl}, 0.35 \mathrm{~g} \mathrm{KH}_{2} \mathrm{PO}_{4}$, $1.95 \mathrm{~g} \mathrm{MES}, 1 \mathrm{~g} \mathrm{NaHCO}, 10 \mathrm{~g}$ sulphur, $1 \mathrm{ml}$ trace element mixture (Widdel \& Bak, 1992), $1 \mathrm{ml}$ selenite tungstate solution (Widdel \& Bak, 1992), $1 \mathrm{ml}$ vitamin mixture (Widdel \& Bak, 1992), $1 \mathrm{ml}$ thiamin solution (Widdel \& Bak, 1992), $1 \mathrm{ml}$ vitamin $B_{12}$ solution (Widdel \& Bak, 1992), $1 \mathrm{ml}$ growth-stimulating factors [per $100 \mathrm{ml}$ distilled water: $0.5 \mathrm{~g}$ isobutyric acid, $0.5 \mathrm{~g}$ valeric acid, $0.5 \mathrm{~g}$ 2-methyl-butyric acid, $0.5 \mathrm{~g}$ 3-methyl-butyric acid, $0.2 \mathrm{~g}$ caproic acid and $0.6 \mathrm{~g}$ succinic acid (Pfennig et al., 1981)] and $1 \mathrm{mg}$ resazurin. The $\mathrm{pH}$ of the medium was adjusted to 6.2 using $1 \mathrm{M} \mathrm{NaOH}$ before autoclaving. $\mathrm{H}_{2}-\mathrm{CO}_{2}(80: 20 ; 200 \mathrm{kPa})$ was used as the gas phase. Unless indicated otherwise, cultures were incubated at $65^{\circ} \mathrm{C}$ and the $\mathrm{pH}$ of the medium was readjusted after $1 \mathrm{~h}$ incubation. Stock cultures of isolate $\mathrm{BSA}^{\mathrm{T}}$ were stored in culture medium at $4{ }^{\circ} \mathrm{C}$. For long-term storage, pure cultures were stored at $-80^{\circ} \mathrm{C}$ in the same medium containing $20 \%(\mathrm{w} / \mathrm{v})$ glycerol.

Determination of growth. Despite the presence of sulphur in the ASR medium, growth was determined by measuring changes in turbidity at $600 \mathrm{~nm}$ by inserting anoxic culture tubes directly into a Spectronic 20D spectrophotometer (Bioblock). Direct cell counts were determined using cells stained with acridine orange and counted by epifluorescence microscopy using an ocular grid (Hobbie et al., 1977). All growth experiments were performed in duplicate.

Determination of growth parameters. The influence of the $\mathrm{pH}$ on growth was determined in the culture medium with various buffer systems at a concentration of $10 \mathrm{mM}$, acetate/acetic acid buffer from $\mathrm{pH} 4$ to $5, \mathrm{MES}$ at $\mathrm{pH} 5.5$ and 6.0, PIPES at $\mathrm{pH} 6.5$ and 7.0, HEPES at $\mathrm{pH} 7.5$, Tris at $\mathrm{pH}$ 8 and 8.5 . The $\mathrm{pH}$ of the medium was adjusted after $1 \mathrm{~h}$ incubation at the optimal temperature for growth. To determine the salt requirement, ASR medium was prepared with different dilutions of sea salts, and incubation was performed at the optimal temperature and optimal $\mathrm{pH}$ for growth.

Determination of growth requirements. To investigate the ability to use substrates other than $\mathrm{H}_{2}$, acetate $\left(2 \mathrm{~g} \mathrm{l}^{-1}\right)$, formate $\left(5 \mathrm{~g} \mathrm{l}^{-1}\right)$, methanol $(0.5 \% ; \mathrm{v} / \mathrm{v})$, monomethylamine $\left(2 \mathrm{~g} \mathrm{l}^{-1}\right)$ and Difco yeast extract $\left(2 \mathrm{~g} \mathrm{l}^{-1}\right)$ were added to the ASR medium with a $\mathrm{N}_{2}-\mathrm{CO}_{2}$ gas phase $(80: 20 ; 200 \mathrm{kPa})$. The same compounds at the same concentrations were also tested as possible carbon sources by using $\mathrm{H}_{2}(100 \%$; $200 \mathrm{kPa}$ ) as the gas phase. Selected nitrogenous compounds were tested for suitability as nitrogen sources, using ammonium-free mineral medium (Widdel \& Bak, 1992) supplemented with sulphur. Nitrogenous compounds were added at $10 \mathrm{mM}$ final concentrations. Electron acceptors were tested in the same medium without $\mathrm{Na}_{2} \mathrm{SO}_{4}$ and sulphur.

Antibiotic susceptibility. Sensitivity to the antibiotics chloramphenicol, penicillin G, streptomycin and rifampicin (Sigma) was tested at a concentration of $100 \mu \mathrm{g} \mathrm{ml} \mathrm{m}^{-1}$. Simultaneous experiments with the bacterium Thermotoga maritima, used as a control, were performed to establish the efficiency of the antibiotics at $70^{\circ} \mathrm{C}$.

Determination of catalase. About $100 \mu \mathrm{l}$ of a $3 \%(v / v) \mathrm{H}_{2} \mathrm{O}_{2}$ solution was dropped onto packed cells from a $20 \mathrm{ml}$ culture. 
The presence of catalase was indicated by the development of gas bubbles.

Light and electron microscopy. An Olympus $\mathrm{BH}-2$ microscope equipped with an Olympus OM-2 camera was used routinely to observe and count the bacteria and to obtain photomicrographs. Gram staining was carried out as described by Conn et al. (1957). For negative staining, $20 \mu \mathrm{l}$ of a bacterial suspension fixed with $2 \%(\mathrm{w} / \mathrm{v})$ glutaraldehyde was dropped on Formvar/carbon-coated grids (400 mesh) and stained with $4 \%(\mathrm{w} / \mathrm{v})$ uranyl acetate. Preparation of cells for freeze fracturing and ultrathin sectioning was performed as described previously (Sleytr et al., 1988). Micrographs were taken on a model CM100 electron microscope (Philips) with an acceleration voltage of $80 \mathrm{kV}$.

$\mathrm{H}_{2} \mathrm{~S}$ determination. Sulphide determination was carried out according to Cline (1969). Samples for $\mathrm{H}_{2} \mathrm{~S}$ determination were stabilized as $\mathrm{ZnS}$ by combining the samples with an excess of $\mathrm{ZnSO}_{4}$ in $1 \mathrm{M} \mathrm{NaOH}$ (Ingvorsen \& Jorgensen, 1979).

Lipid analysis. Dried cells (300 mg) were extracted and analysed by TLC as described by De Rosa \& Gambacorta (1994). The total lipid extract was purified by flash chromatography on silica gel and eluted with chloroformmethanol- $\mathrm{H}_{2} \mathrm{O}(65: 25: 4$, by vol. $)$. The final purification was achieved by TLC developed with chloroform-methanol$\mathrm{H}_{2} \mathrm{O}(65: 25: 4$, by vol.). The spots, visualized by iodine vapour, were scraped and eluted by chloroform-methanol $(1: 1)$. The compounds were analysed by ${ }^{1} \mathrm{H}$ - and ${ }^{13} \mathrm{C}$-NMR. The compounds were hydrolysed by alkaline methanolysis as reported previously (Soriente et al., 1992). The methanol mixture was analysed by TLC developed with $n$-hexaneethyl acetate $(96: 4, \mathrm{v} / \mathrm{v})$, and the hydrolysis products were detected by exposure to iodine vapour and spraying with $0 \cdot 1 \%(\mathrm{w} / \mathrm{v}) \mathrm{Ce}\left(\mathrm{SO}_{4}\right)$. The hydrolysis products were purified by preparative TLC with the solvent system described above. Saturated and unsaturated fatty acids were detected by silver nitrate-impregnated TLC $\left[10 \%(\mathrm{w} / \mathrm{v}) \mathrm{AgNO}_{3}\right]$. The methanol-soluble fraction was analysed by ${ }^{1} \mathrm{H}-\mathrm{NMR}$ and GC-MS.

NMR spectra were recorded on a Bruker AMX 500 $\left(500.13 \mathrm{MHz}\right.$ for ${ }^{1} \mathrm{H}$ and $125.75 \mathrm{MHz}$ for ${ }^{13} \mathrm{C}$ ) spectrometer. Chemical shifts are given in p.p.m. $(\delta)$ scale; the methanol signal was used as an internal standard $\left(\delta 7 \cdot 26{ }^{1} \mathrm{H} ; \delta 77 \cdot 0\right.$ $\left.{ }^{13} \mathrm{C}\right)$. The spectra were performed in $\mathrm{CDCl}_{3}-$ methanol $(1: 1)$ for polar lipids and in $\mathrm{CDCl}_{3}$ for fatty acid methyl esters (FAME). Distortionless enhancement by polarization transfer (DEPT) experiments were performed according to the methods of Doddrell et al. (1982).

GC-MS runs were obtained using a Hewlett-Packard 5890 series II plus-5989B spectrometer equipped with a HP-V column with a flux of $45 \mathrm{ml} \mathrm{min}{ }^{-1}$. FAME analyses were performed under the following conditions: initial temperature $120^{\circ} \mathrm{C}(1 \mathrm{~min})$; rate $2{ }^{\circ} \mathrm{C} \mathrm{min}^{-1}$; final temperature $250^{\circ} \mathrm{C}$.

Isolation of DNA. Genomic DNA of strain $\mathrm{BSA}^{\mathrm{T}}$ was isolated using a modification of the procedure described by Charbonnier \& Forterre (1994). The DNA was purified on a caesium chloride gradient (Sambrook et al., 1989), and purity was checked spectrophotometrically.

DNA base composition. The $\mathrm{G}+\mathrm{C}$ content of the DNA was determined from the melting point according to Marmur \& Doty (1962) using Escherichia coli DNA ( $57 \mathrm{~mol} \% \mathrm{G}+\mathrm{C}$ ), Clostridium perfringens DNA $(26.5 \mathrm{~mol} \% \mathrm{G}+\mathrm{C})$ and Micrococcus luteus DNA ( $77 \mathrm{~mol} \% \mathrm{G}+\mathrm{C})$ as standards.
PCR amplification and sequencing of the small subunit rDNA. Purifed DNA was used in a PCR to amplify the small subunit rDNA gene. To amplify the small subunit rDNA, the forward primer was $5^{\prime}<$ AGAGTTTGATCCTGGCTCAG $<3^{\prime}$, and the reverse primer was $5^{\prime}<$ GGTTACCTTGTTACGACTT $<3^{\prime}$, corresponding, respectively, to the following positions in the $E$. coli rRNA sequence (Brosius $e t$ al., 1978): 8-27 and 1492-1510. The initial denaturation step consisted of heating the reaction mixture at $95^{\circ} \mathrm{C}$ for $180 \mathrm{~s}$, and the thermal profile then consisted of 25 cycles of annealing at $52^{\circ} \mathrm{C}$ for $60 \mathrm{~s}$, extension at $72^{\circ} \mathrm{C}$ for $90 \mathrm{~s}$ and denaturation at $94^{\circ} \mathrm{C}$ for $30 \mathrm{~s}$. A final extension step was carried out at $72{ }^{\circ} \mathrm{C}$ for $5 \mathrm{~min}$. The PCR products were analysed on a $1 \%$ low-melting-point agarose gel that included a molecular mass standard for quantification of the PCR yield.

PCR products were sequenced with a Thermo Sequenase premixed cycle sequencing kit (Amersham) as recommended by the manufacter. Sequence reaction mixtures were electrophoresed using a Vistra Systems model 725 DNA sequencer. The forward and reverse primers used to amplify the $16 \mathrm{~S}$ rDNA genes were also used for sequencing. Internal sequences of the genes were obtained by using a forward primer $\left(5^{\prime}<\right.$ GTGCCAGC(AC)GCCGCGGTAA < $\left.3^{\prime}\right)$ and a reverse primer corresponding to positions 515-534, and a forward primer $\left(5^{\prime}<\right.$ GAAACTTAAA(GT)GAATTG $<3^{\prime}$ ) corresponding to positions 906-924 (according to the $E$. coli numbering).

Phylogenetic analysis of the rDNA genes. The 16S rDNA sequences were aligned manually with the sequences of representatives of related genera. The organisms used in this analysis and their small subunit rRNA sequence accession numbers retrieved from the EMBL sequence database were as follows: Aquifex pyrophilus $\mathrm{Kol}^{5 \mathrm{a}^{\mathrm{T}}}\left(=\mathrm{DSM} 6858^{\mathrm{T}}\right)$, M83548; Hydrogenobacter thermophilus TK $-6^{\mathrm{T}}$ (= DSM $6543^{\mathrm{T}}$ ), Z30214; Calderobacterium hydrogenophilum Z-829 $\left(=\mathrm{DSM} 2913^{\mathrm{T}}\right), \quad \mathrm{Z} 30242 ;$ Geotoga subterranea $\mathrm{CC}-1^{\mathrm{T}}$, L10659; Fervidobacterium nodosum Rt17-B1 ${ }^{\mathrm{T}}$, M59177; Thermotoga maritima MSB8 $8^{\mathrm{T}}$ (= DSM $3109^{\mathrm{T}}$ ), M21774; Thermus thermophilus $\mathrm{HB} 8^{\mathrm{T}}$, X07998. The secondary structure was used as a guide to ensure that only homologous regions were compared. Regions with undetermined nucleotides for the sequences available in the EMBL database were not included within these analyses. A total of 1447 nucleotides were sequenced, and 959 were used in the phylogenetic analysis.

Three phylogenetic methods included in the program PHYLO_WIN (Galtier et al., 1996) were used : (i) a neighbourjoining algorithm like that developed by Saitou and Nei (1987); the analyses were performed using the Kimura distance option, which corrected for multiple substitutions according to the two-parameter model, allowing for unequal transition and transversion rates; (ii) a maximum parsimony algorithm using the PHYLIP package (Felsenstein, 1993); and (iii) a maximum-likelihood analysis, using the FASTDNAML program (Olsen et al., 1994).

All trees obtained with these phylogenetic methods were plotted using a Macintosh computer and a program (NJPLOT) developed by M. Gouy (URA 243 CNRS, Université Claude Bernard, Villeurbanne, France) that allows the transformation of a formal tree representation (Newick's format) into Claris Draw drawings. Only topologies that were found to be similar by all three methods were retained as 'true trees'. Theoretical works have indeed demonstrated that convergence of the results of all three methods is a very strong 
indication that the correct phylogeny has been determined and that the tree topology found was robust (Huelsenbeck \& Hillis, 1993; Kim, 1993).

\section{RESULTS}

\section{Enrichment and isolation}

To enrich for autotrophic, sulphur-reducing thermophiles, $10 \mathrm{ml}$ ASR medium was inoculated with approximately $1 \mathrm{ml}$ chimney suspensions. The enrichments were performed in $50 \mathrm{ml}$ vials with $\mathrm{H}_{2}-\mathrm{CO}_{2}$ as the gas phase $(80: 20 ; 200 \mathrm{kPa})$ without shaking at $65^{\circ} \mathrm{C}$. Within 2-3 d, turbidity caused by cell growth was observed. This growth consisted of small highly motile rods. $\mathrm{H}_{2} \mathrm{~S}$ was produced with the reduction of sulphur. All positive enrichment cultures could be transferred successfully in the same medium. To obtain pure cultures, subcultures were streaked onto solidified medium and incubated in an anaerobic jar with the same gas phase at $65^{\circ} \mathrm{C}$. On solid medium, round white colonies ( $1 \mathrm{~mm}$ in diameter) were visible after incubation for up to $3 \mathrm{~d}$. Strain $\mathrm{BSA}^{\mathrm{T}}$, which was the first obtained in pure culture after three successive streakings on plates, was studied in detail. Packed cell masses exhibited a pink colour.

\section{Morphology}

Cells of strain $\mathrm{BSA}^{\mathrm{T}}$ appeared as small rods, about 1-2 $\mu \mathrm{m}$ long and $0.4-0.5 \mu \mathrm{m}$ wide (Fig. $1 \mathrm{a}$ and $\mathrm{b}$ ), and stained Gram-negative. They occurred singly or in pairs. Under the microscope, the cells appeared to be
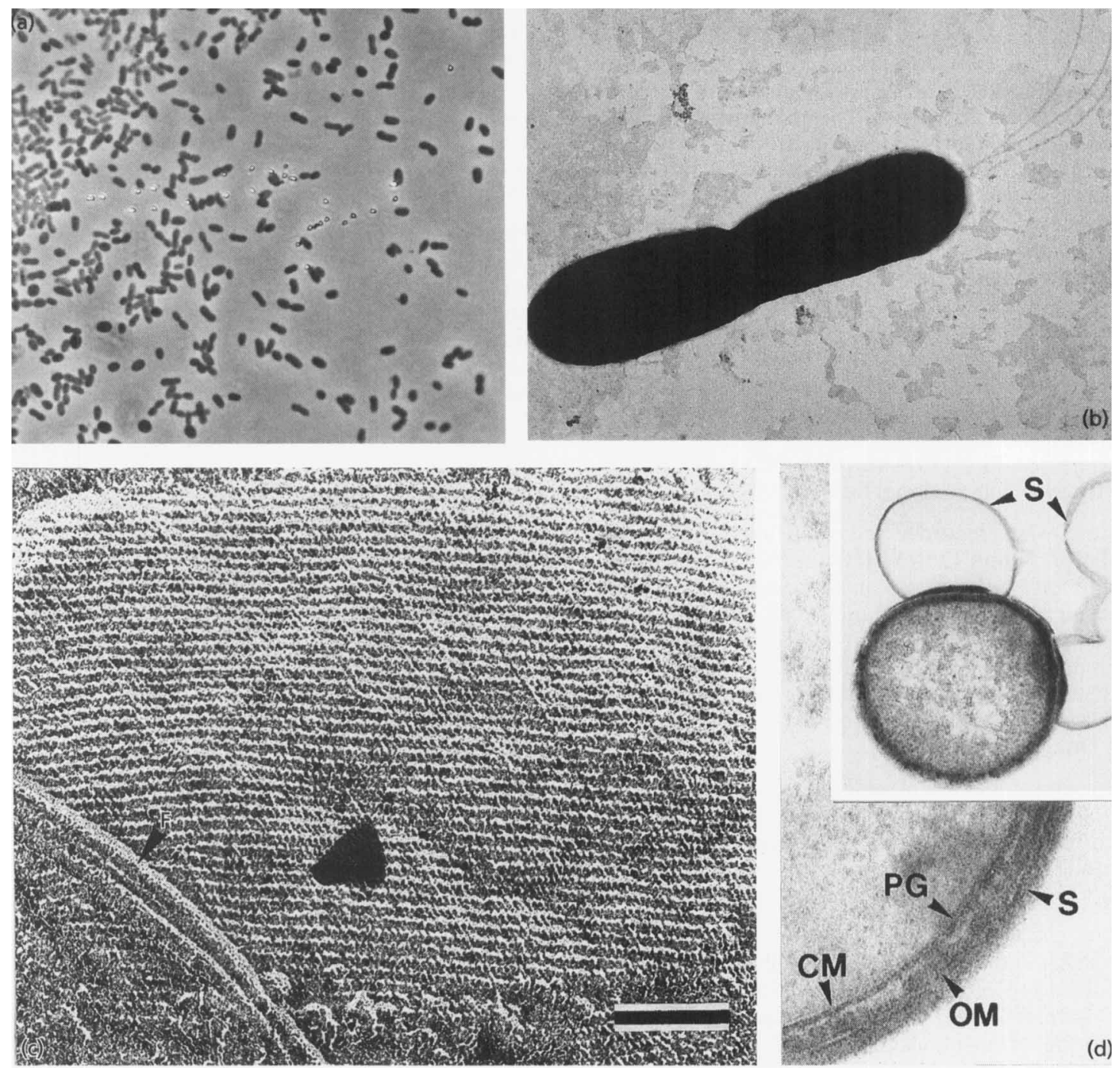

Fig. 1. Phase-contrast (a) and electron (b-d) micrographs of isolate $B S A^{\top}$. Negatively stained dividing cell (b) showing polar flagella (bar, $200 \mathrm{~nm}$ ). Freeze-etched cells and metal-shadowed intact cells of isolate BSA ${ }^{\top}$ (c) showing the S-layer lattice; F, flagella (bar, $100 \mathrm{~nm}$ ). By ultrathin section, the typical cell envelope of a Gram-negative bacterium becomes visible (d); S, S-layer; OM, outer membrane; CM, cytoplasmic membrane; PG, peptidoglycan layer. Inset: portions of the $S$-layer peeling off the outer membrane; $S$, S-layer. 

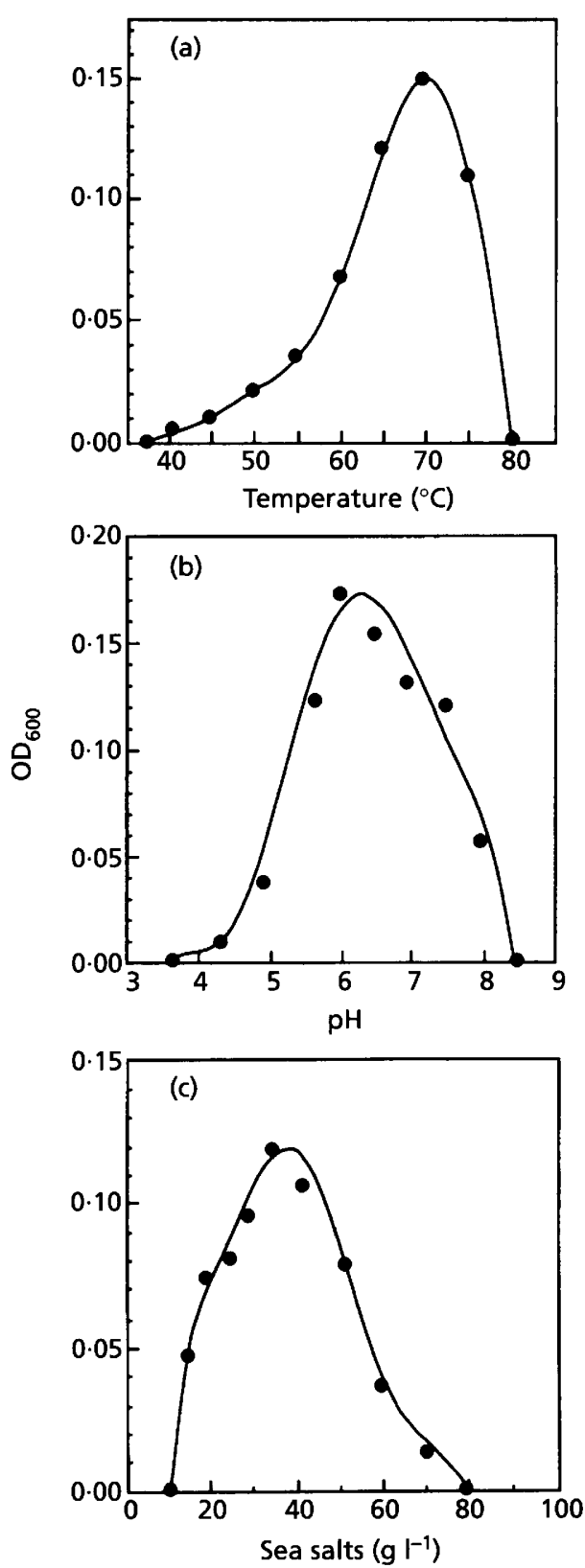

Fig. 2. Effect of temperature, $\mathrm{pH}$ and concentration of sea salts on growth of isolate $\mathrm{BSA}^{\top}$ in ASR medium. Final optical densities measured at $600 \mathrm{~nm}$ after $10-12 \mathrm{~h}$ incubation are plotted as a function of temperature (in the presence of $30 \mathrm{~g}$ sea salts $\mathrm{I}^{-1}$ at $\mathrm{pH} 6.25$ ) (a), $\mathrm{pH}$ of the medium (in the presence of $30 \mathrm{~g}$ sea salts $\mathrm{I}^{-1}$ at $70^{\circ} \mathrm{C}$ ) (b) and concentration of sea salts (at $70^{\circ} \mathrm{C}$ and at $\mathrm{pH} 6 \cdot 25$ ) (c).

highly motile, and up to three flagella could be observed by negative staining (Fig. 1b). In the stationary growth phase, some rods became spherical. Freeze fracturing of intact cells showed that the organism is completely covered with an oblique S-layer lattice with centre-to-centre spacings of approximately 11.3 and $6.3 \mathrm{~nm}$ and an angle $\gamma$ between the lattice vectors of approximately $80^{\circ}$ (Fig. 1c). Ultrathin sections clearly

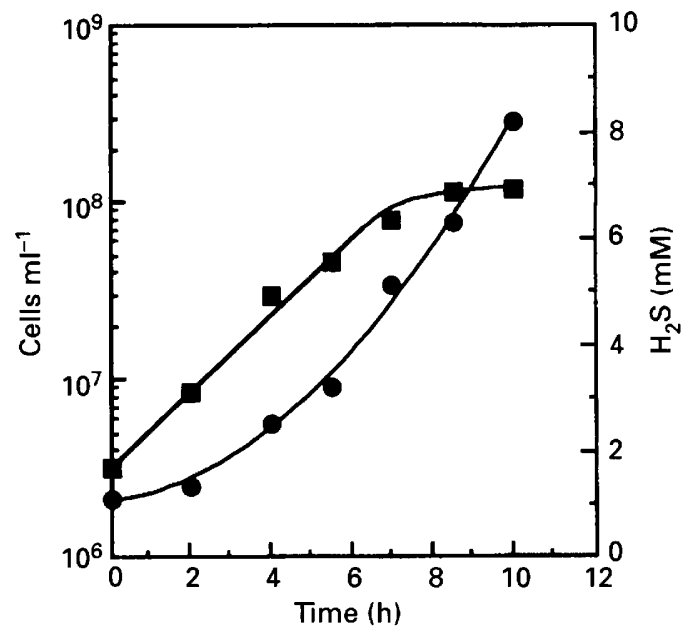

Fig. 3. Growth of $(\square)$ and sulphide production by (O) strain BSA $^{\top}$ cultivated under optimal conditions in ASR medium with sulphur as energy source.

demonstrated that strain $\mathrm{BSA}^{\mathrm{T}}$ possesses the typical cell envelope profile of Gram-negative bacteria with a cytoplasmic and an outer membrane (Fig. 1d). The Slayer on top of the outer membrane very frequently peels off forming large loops (Fig. 1d, insert).

\section{Determination of growth parameters}

Strain $\mathrm{BSA}^{\mathrm{T}}$ grew between 40 and $75^{\circ} \mathrm{C}$ with an optimum around $70^{\circ} \mathrm{C}$, while no growth was detected at 37 and $80^{\circ} \mathrm{C}$ after $48 \mathrm{~h}$ incubation (Fig. 2a). Growth was observed between $\mathrm{pH} 4.4$ and 8 , with an optimum around $\mathrm{pH} 6$ (Fig. 2b). No growth was detected at $\mathrm{pH}$ 3.7 or 8.5 after $48 \mathrm{~h}$ incubation at $70^{\circ} \mathrm{C}$. Growth could be observed at sea salts concentrations ranging from 15 to $70 \mathrm{~g}^{-1}$ (Fig. $2 \mathrm{c}$ ), with an optimum of approximatively $35 \mathrm{~g} \mathrm{l}^{-1}$ (corresponding to $23 \mathrm{~g} \mathrm{NaCl} \mathrm{l}^{-1}$ ). No growth was observed at sea salts concentrations of 10 and $80 \mathrm{~g}^{-1}$ after $48 \mathrm{~h}$ incubation at $70^{\circ} \mathrm{C}$. Under optimal growth conditions (temperature, $\mathrm{pH}$ and $\mathrm{NaCl}$ ), the doubling time of strain $\mathrm{BSA}^{\mathrm{T}}$ was around $135 \mathrm{~min}$.

\section{Determination of growth requirements}

Strain BSA $^{\mathrm{T}}$ was a strictly anaerobic, autotrophic organism that used sulphur as an electron acceptor in the presence of $\mathrm{H}_{2}$ for growth. Of the alternative electron acceptors tested in combination with $\mathrm{H}_{2}$ as an electron donor, strain $\mathrm{BSA}^{\mathrm{T}}$ used thiosulphate, and sulphite and polysulphides slightly. It did not use cystine, sulphate, nitrate or nitrite. Growth on sulphur, thiosulphate, polysulphides and sulphite was accompanied by exponential $\mathrm{H}_{2} \mathrm{~S}$ production that paralleled growth. On sulphur-supplemented medium, when cells entered the stationary phase, the $\mathrm{H}_{2} \mathrm{~S}$ concentration approached $9 \mu \mathrm{M}$ (Fig. 3). No growth was observed on acetate, formate, methanol, monomethylamine and 
yeast extract with a $\mathrm{N}_{2}-\mathrm{CO}_{2}$ or $\mathrm{H}_{2}$ headspace, with or without sulphur. Nitrate, tryptone and yeast extract were used as nitrogen sources. When supplemented individually in the basal medium plus sulphur, vitamin B12, vitamin mixture and tungstate-selenate solution (see Methods section) stimulated the growth yield by a factor of two to three, wheareas trace element solution and thiamin had no similar effect. Yeast extract $(0.2 \%)$ was found to be slightly inhibitory (data not shown). The new organism was not able to grow in the ASR medium in the presence of oxygen, even at low concentrations $(0 \cdot 2-1 \%)$. By using the same culture conditions (with $20 \mathrm{mM}$ thiosulphate and $\mathrm{H}_{2}-\mathrm{CO}_{2}-\mathrm{O}_{2}$ $(79 \cdot 75: 19 \cdot 75: 0 \cdot 5)$ as the gas phase, Aquifex pyrophilus, Hydrogenobacter thermophilus and Calderobacterium hydrogenophilum showed good growth.

\section{Sensitivity to antibiotics}

Growth of strain BSA $^{\mathbf{T}}$ was inhibited by chloramphenicol, penicillin $G$ and rifampicin but not by streptomycin when added before incubation at the optimum temperature.

\section{Determination of catalase}

No gas development was observed when cells of strain BSA $^{\mathrm{T}}$ were flooded with $\mathrm{H}_{2} \mathrm{O}_{2}$. Cells of Aquifex pyrophilus, used as a positive control, exhibited gas production.

\section{Sensitivity to lysozyme}

After the addition of lysozyme $\left(5 \mathrm{mg} \mathrm{ml}^{-1}\right.$ final concentration), exponentially growing cells of strain $\mathrm{BSA}^{\mathrm{T}}$ remained morphologically unchanged during a $3 \mathrm{~h}$ period of microscopic inspection.

\section{Lipid analysis}

The total lipid content of strain $\mathrm{BSA}^{\mathrm{T}}$ was about $6 \%$ of the total dry weight. The polar lipid pattern of the new organism was characterized by the presence of two main components, an aminophospholipid (about $66 \%, R_{f} 0 \cdot 7$ ) and a phospholipid (about $30 \%, R_{f} 0 \cdot 5$ ) and minor compounds. The first spot had an $R_{f}$ value lower than that of phosphoethanolamine, while the phospho-positive one had the same $R_{f}$ value as phosphoinositol.

The ${ }^{1} \mathrm{H}$ NMR spectrum of the phospholipid was similar to that of a phosphoinositol derivative of glycerol esterified with saturated and unsaturated acyl chains. The signals between 4.47 and 3.63 p.p.m., in addition to the signals caused by the disubstituted glycerol with fatty acids, gave coupling constant values typical of inositol (Ferrante et al., 1988). The ${ }^{13} \mathrm{C}$ NMR spectra showed resonances between 14 and 35 p.p.m. typical of a straight acyl chain, together with a signal at 130 p.p.m. resulting from an unsaturation. In the low-field part of the spectra (60-70 p.p.m.), there were signals typical of a glycerol, which was linked to phosphorus at the primary carbon. In fact, the signal at $70.6 \delta$ showed a large coupling constant of $8.1 \mathrm{~Hz}$ resulting from the carbon-2 of glycerol, typical of a coupling with a phosphorus of the secondary carbon. In addition, six signals were found, all originating from the methine group (from the DEPT experiment), with chemical shift values falling within a narrow range of 70-77 p.p.m., suggesting an inositol head group. Therefore, the phosphorus-positive compound was identified as a phosphoinositol derivative of 1,2diacylglycerol.

The ${ }^{1} \mathrm{H}$ NMR spectrum of the phosphoamino-positive compound showed resonances typical of a glycerol esterified with saturated and unsaturated fatty acids, as described above. Moreover, a signal at $3.3 \delta$, attributable to the methylene linked to $\mathrm{NH}_{2}$, and a complex pattern of signals between 3.4 and $4.12 \delta$ were also present. The ${ }^{13} \mathrm{C}$ NMR spectrum confirmed the ${ }^{1} \mathrm{H}$ NMR spectrum. In addition to the resonances typical of the bisubstituted glycerol with saturated and unsaturated straight-chained fatty acids, resonances were present from a methylene residue (from the DEPT experiment) at $\delta 41 \cdot 3$, which is attributable to the $\mathrm{CH}_{2} \mathrm{NH}_{2}$, and from some $\mathrm{CH}$ residues between 72 and 78 p.p.m. Two-dimensional homonuclear shift correlation NMR experiments were not sufficient to clarify the structure of this compound, but that will be completely elucidated when more material becomes available.

FAME fraction analyses of both compounds revealed the presence of saturated and monounsaturated acyl chains. The major FAME components were identified by NMR and GC-MS studies. NMR spectra gave information on the presence of straight acyl chains. Proton spectra showed the presence of the methyl triplet at $0.89 \delta$ attributable to the terminal methyl group of the normal (n) FAME. The spectra showed the typical signals of bulk methylenes at $1.25 \delta$, of $\alpha$ $\mathrm{CH}_{2}$ at $\delta 2 \cdot 29-2 \cdot 30$ and of $\beta-\mathrm{CH}_{2}$ at $\delta 1.67$. In addition, a broad multiplet was present at $\delta 2.0$ caused by the methylene $\alpha$ forming a double bond. Finally, a multiplet was also found at $\delta 5.35$ as a result of the double bonding methines. The ${ }^{13} \mathrm{C}$ NMR spectra confirmed the proton NMR spectra; the terminal methyl at $\delta 14.5$, the methylenes (from the DEPT experiment) between 22 and 35 p.p.m. and, finally, a signal at $\delta 130$ caused by methine (from the DEPT experiment) were present.

The GC-MS allowed the identification of the major components unambiguously. FAME composition of the two polar lipids was very similar. The phosphoinositol contained $\mathrm{nC} 16: 0$ (15\%), C18:1 (41\%) identified as methyl oleate, and $\mathrm{nC} 18: 0(44 \%)$ identified as stearate. The phosphoamino-positive compound contained $\mathrm{nC} 16: 0(14 \%), \mathrm{C} 18: 1$ (43\%), nC18:0 (31\%) and $\mathrm{nC} 20: 0(12 \%)$. Minor compounds were also present. 


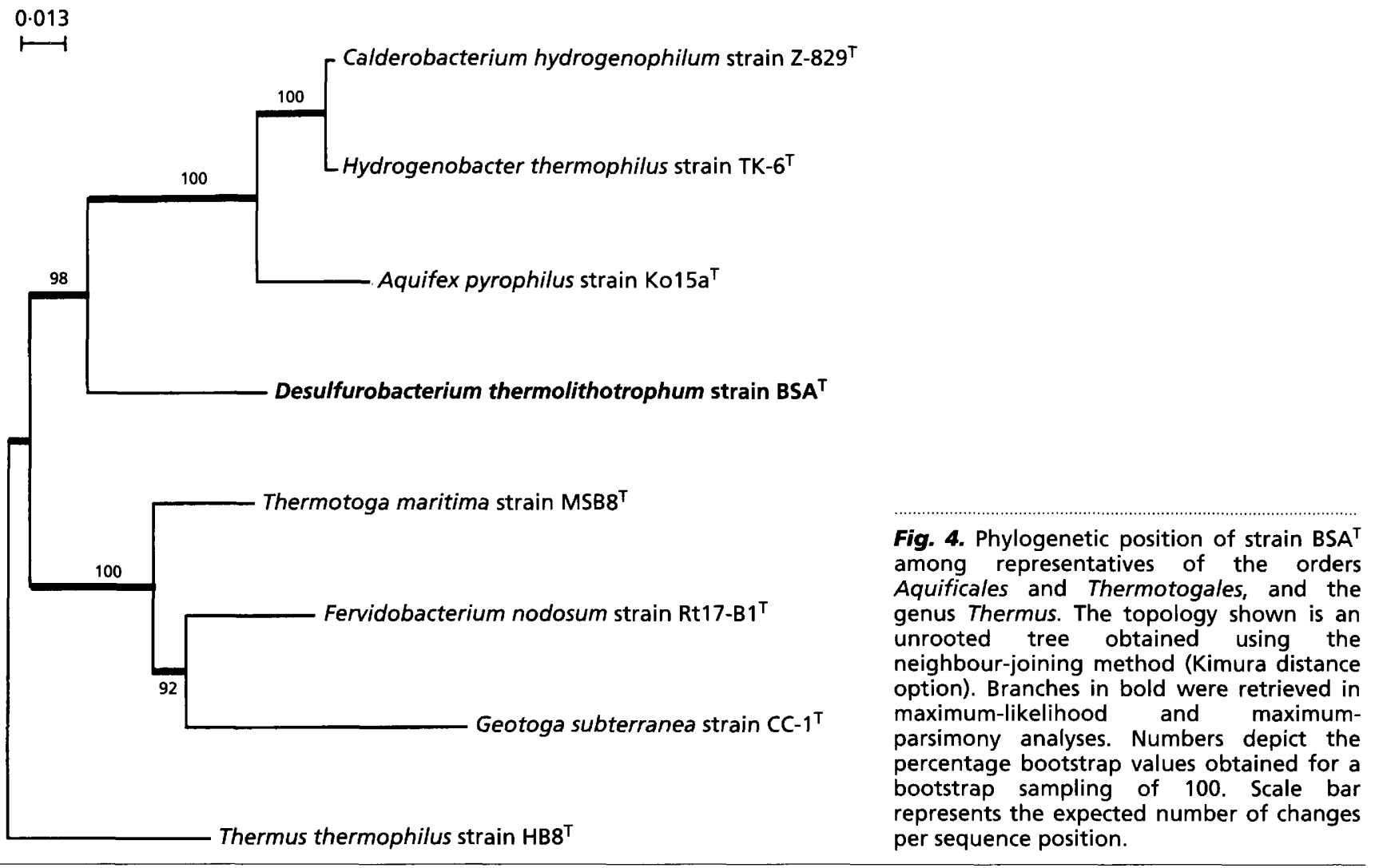

\section{DNA base composition}

The $\mathrm{G}+\mathrm{C}$ content of the DNA of strain $\mathrm{BSA}^{\mathrm{T}}$ determined by the thermal denaturation method was $35 \mathrm{~mol} \%$. As a control, the base composition of Fervidobacterium nodosum was determined to be 35 $\mathrm{mol} \%$ [ $34 \mathrm{~mol} \%$ by the $T_{\mathrm{m}}$ method (Patel et al., 1985) and by liquid chromatography (Huber et al., 1990)].

\section{S rDNA sequence analysis}

The phylogenetic position of the organism was investigated in detail by including representatives of different genera of thermophilic bacteria. The analyses were performed using three methods: neighbour joining, maximum likelihood and maximum parsimony. The results of all analyses were always consistent, regardless of which method was used or which species were chosen for comparison (data not shown). The same topology of tree was obtained with the three methods and with the different options chosen for the distance-based tree-making methods (Jukes-Cantor distance or Kimura two-parameter distance). The transition-transversion ratio was to 0.91 (mean over all sequence pairs).

In all analyses, the trees obtained showed the existence of two monophyletic units composed of: (i) the genera Calderobacterium, Hydrogenobacter and Aquifex; and (ii) the genera Thermotoga, Fervidobacterium and Geotoga (Fig. 4). The internal branches for both monophyletic units were supported by maximum- likelihood analysis and by bootstrap analysis using the parsimony method (100\% of bootstrap replications). The distinctness of the branch that supported strain BSA $^{\mathrm{T}}$ with the genera cited above and the relationship between the new strain and the cluster containing the Aquificales were determined by all phylogenetic analysis methods used and retrieved in $98 \%$ of bootstrap replications. The levels of similarity between strain $\mathrm{BSA}^{\mathrm{T}}$ and the reference organisms that were analysed were less than $90 \%$. The highest level of $16 \mathrm{~S}$ rDNA similarity was the level of similarity with Calderobacterium hydrogenophilum $(88 \cdot 1 \%)$.

\section{DISCUSSION}

The new isolate $\mathrm{BSA}^{\mathrm{T}}$ is a Gram-negative, marine, obligately chemolithoautotrophic bacterium that grows under anaerobic conditions with sulphur compounds as electron acceptors. Its optimum growth temperature is $70^{\circ} \mathrm{C}$. On account of its ultrastructural features, its lipid composition and its 16S rDNA sequence, the isolate belongs to the phylogenetic domain of the Bacteria (Langworthy \& Pond, 1986; Woese et al., 1990; Sleytr et al., 1996).

The $\mathrm{G}+\mathrm{C}$ content of the DNA of strain $\mathrm{BSA}^{\mathrm{T}}$ is 35 $\mathrm{mol} \%$. This value is within the range of values obtained for the phylogenetically related genera (Kawasumi et al., 1984; Patel et al., 1985; Huber et al., 1986, 1989, 1990, 1992; Jannasch et al., 1988; Windberger et al., 1989; Jeanthon et al., 1995; Antoine et 


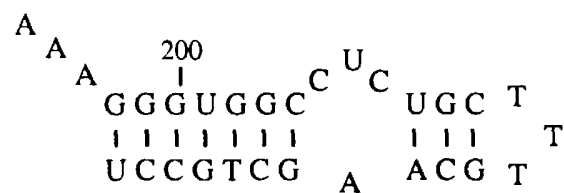

Desulfurobacterium thermolithotrophum

A

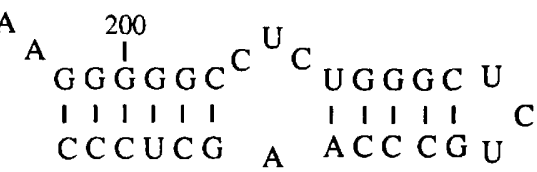

Aquifex pyrophilus

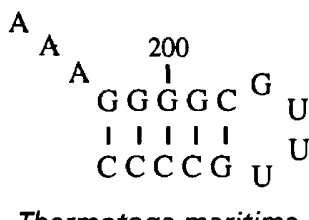

Thermotoga maritima

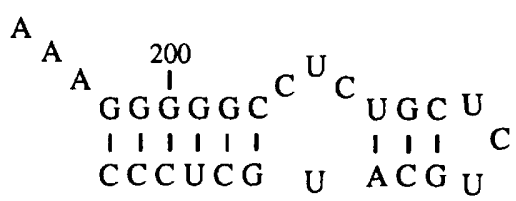

Hydrogenobacter thermophilus

Fig. 5. Putative secondary structure in the vicinity of position 200 of the $16 \mathrm{~S}$ rRNA sequences of strain $\mathrm{BSA}^{\top}$, Aquifex pyrophilus $\mathrm{Kol}^{5 \mathrm{a}^{\top}}$ (= DSM $6858^{\top}$ ), Thermotoga maritima MSB8 (= DSM 3109 ${ }^{\top}$ ) and Hydrogenobacter thermophilus TK $-6^{\top}$ (= DSM 6543').

al., 1997): Hydrogenobacter ( $\mathrm{G}+\mathrm{C}$ content, 35-44 mol\%), Aquifex (40 mol\%), Thermotoga (40$46 \mathrm{~mol} \%)$, Thermosipho $(30 \mathrm{~mol} \%)$, Fervidobacterium (34 $41 \mathrm{~mol} \%)$, Geotoga $(30 \mathrm{~mol} \%)$ and Petrotoga $(40 \mathrm{~mol} \%)$. The phylogenetic analysis based on the $16 \mathrm{~S}$ rDNA sequence indicates that strain $\mathrm{BSA}^{\mathrm{T}}$ is not specifically affiliated with one of the genera already existing and represents a line of descent that is distinct and almost equidistant from the previously described deeply branching thermophilic genera (Pitulle et al., 1994). However, strain $\mathrm{BSA}^{\mathrm{T}}$ shares a secondary structural feature with members of the order Aquificales (Burggraf et al., 1992). The helix found at positions 198-219 in the 16S rRNA secondary structure (E. coli numbering) is characterized by a CUC bulge and a single nucleotide bulge (Fig. 5). This motif, found elsewhere only in the $\delta$ group of proteobacteria (Woese, 1987), has been suggested to represent a defining signature of the Aquificales lineage (Reysenbach et al., 1994).

The most closely related bacterial groups, members of the order Thermotogales and Aquifex, possess ether lipids (Windberger et al., 1989; Huber et al., 1992; Jeanthon et al., 1995). In contrast, no ether lipids were detected in strain $\mathrm{BSA}^{\mathrm{T}}$ with the methods used. In addition, lipids of the new organism contained large amounts of monounsaturated C18:1 fatty acids. Unsaturated acyl chains were found recently in the hyperthermophiles Thermotoga maritima and Pyrococcus furiosus, where they represented about 10 and $1 \%$ of the total lipids, respectively (Carballeira et al., 1997). The synthesis of high-melting-point fatty acids $(\mathrm{C} 18$ and $\mathrm{C} 20)$ is favoured in strain $\mathrm{BSA}^{\mathrm{T}}$. This strategy may probably ensure the functionality of the membrane at high growth temperatures.

Strain BSA $^{\mathrm{T}}$ shares some characteristics with its phylogenetic relatives but also exhibits significant physiological differences. The physiology of strain $\mathrm{BSA}^{\mathrm{T}}$ is not consistent with that of members of the order Thermotogales, which always produce a 'sheath' and are strict heterotrophs (Huber \& Stetter, 1992). On the basis of its strict chemolithotrophy, growth on hydrogen, sulphur and thiosulphate as energy sources, its 16S rRNA phylogenetic analysis and its shared secondary structural features, the new organism resembles members of the order Aquificales (Kawasumi et al., 1984; Huber et al., 1992). However, it differs in its inability to grow in microaerophilic conditions. Presumably, in the future, it might be considered as a representative of a novel family.

\section{Ecological significance}

Within the walls of deep-sea hydrothermal vent chimneys, microniches are formed by steep gradients of nutrients, temperatures (from 350 to $2^{\circ} \mathrm{C}$ within a few centimetres), oxygen levels and fluid velocities. Up to now, described primary producers at deep-sea vents comprised only hyperthermophilic Archaea (Jones et al., 1983, 1989; Zhao et al., 1988; Blöchl et al., 1997) and mesophilic Bacteria (Jannasch, 1995). To our knowledge, Desufurobacterium thermolithotrophum represents the first extremely thermophilic bacterium that can act as a primary producer in the temperature range of $45-75^{\circ} \mathrm{C}$. Up to now, little has been known about the ecological distribution of this new organism. We recently designed a rRNA-based probe specific to the members of the order Aquificales that also hybridized with the new isolate (Harmsen et al., 1997b). The combined use of this probe with a probe specific to the domain Bacteria (which, however, did not hybridize with the known members of the order Aquificales) allowed us to quantify in deep-sea hydrothermal vent chimney samples morphologically diverse cells that hybridized with both probes and included the morphotype of strain BSA ${ }^{\mathrm{T}}$ (Harmsen et al., 1997b). The bacterial cells that had sequences identical to the target sequences of both probes used represented up to $40 \%$ 
of the population enumerated using the general bacterial probe. Therefore, strain $\mathrm{BSA}^{\mathrm{T}}$ and these other phylogenetically very closely related thermophilic micro-organisms may play a significant role within marine hydrothermal environments.

On the basis of the combination of distinct physiological properties and phylogenetic position, we propose to describe the new genus as Desulfurobacterium. Desulfurobacterium thermolithotrophum is the type species of this genus, and strain $\mathrm{BSA}^{\mathrm{T}}$ is the type strain of Desulfurobacterium thermolithotrophum.

\section{Description of Desulfurobacterium gen. nov.}

Desulfurobacterium (De.sul.fu.ro.bac. te'ri.um. L. pref. de from; L.n. sulfur sulphur; Gr. neut. dim. n. bakterion a small rod; M.L. neut. n. Desulfurobacterium sulphur-reducing rod-shaped bacterium).

Cells are Gram-negative rods. Spores are not produced. Anaerobic and thermophilic. Neutrophilic. Strictly chemolithotrophic. The $\mathrm{G}+\mathrm{C}$ content of the type species is $35 \mathrm{~mol} \%$. The type species is Desulfurobacterium thermolithotrophum.

\section{Description of Desulfurobacterium thermolithotrophum sp. nov.}

Desulfurobacterium thermolithotrophum (ther.mo.li.tho.tro' phum. Gr. adj. thermos hot; Gr. masc. n. lithos stone; Gr. masc. n. trophos one who feeds; M.L. neut. adj. thermolithotrophum thermophilic and lithotrophic).

Cells are highly motile by means of three polar flagella, occur singly and in pairs and range from 1 to $2 \mu \mathrm{m}$ long by $0.4-0.5 \mu \mathrm{m}$ wide. Whitish colonies about $1 \mathrm{~mm}$ in diameter formed on Phytagel plates. Oblique S-layer lattice. Growth occurs between 40 and $75^{\circ} \mathrm{C}$, with an optimum at approximately $70^{\circ} \mathrm{C}$ (doubling time 135 min). Growth occurs between $\mathrm{pH} 4.4$ and 8 with an optimum of approximately $\mathrm{pH} 6.25$ and at sea salts concentrations ranging from 15 to $70 \mathrm{~g} \mathrm{l}^{-1}$ with an optimum of approximately $35 \mathrm{~g} \mathrm{l}^{-1}$. Sulphur, thiosulphate and sulphite serve as electron acceptors in the presence of $\mathbf{H}_{2}$. Growth is inhibited by chloramphenicol, penicillin $\mathrm{G}$ and rifampicin at $100 \mu \mathrm{g} \mathrm{ml}^{-1}$, but not by streptomycin. Catalase is not produced. DNA base composition of the type strain is $35 \mathrm{~mol} \%$ $\mathrm{G}+\mathrm{C}$ (determined by the thermal denaturation method). The type strain is Desulfurobacterium thermolithotrophum $\mathrm{BSA}^{\mathrm{T}}$, which was obtained from a deep-sea hydrothermal vent chimney at the midAtlantic ridge $\left(23^{\circ} \mathrm{N}\right)$. Strain $\mathrm{BSA}^{\mathrm{T}}$ has been deposited in the DSMZ under accession number DSM $11699^{\mathrm{T}}$.

\section{ACKNOWLEDGEMENTS}

The excellent technical assistance of Andrea Scheberl and Monika Miksa is gratefully acknowledged. The authors also thank Eduardo Pagnotta for lipid analysis, and V. Mirra and S. Zambardino from the NMR-CNR service (Naples) for NMR spectra. The Microsmoke cruise was organized by
CNRS (D. Prieur, chief scientist) with the N.O. 'Le Nadir' and the D.S. V. 'Nautile' operated by Ifremer. We thank the captain and the crew of N. O. 'Le Nadir' and the D. S. V. 'Nautile' pilots for skilful operations and support crew. This work performed at Roscoff was supported by CNRS, GDR 1006 CNRS/Ifremer, CPER 94-95 (Contrat de Plan EtatRégion), Fonds Structurel Européen (FEDER 5b) and MASTIII program from the EEC (contract no. CT95-0034). Grants from the Austrian Science Foundation, project S7201-MOB, and the Austrian Federal Ministry of Science and Transportation supported the work performed in Vienna.

\section{REFERENCES}

Alfredsson, G. A., Kristjansson, J. K., Hjörleifsdöttir, S. \& Stetter, K. O. (1988). Rhodothermus marinus, gen. nov., sp. nov., a thermophilic, halophilic bacterium from submarine hot springs in Iceland. J Gen Microbiol 134, 299-306.

Antoine, E., Cilia, V., Meunier, J. R., Guezennec, J., Lesongeur, F. \& Barbier, G. (1997). Thermosipho melanesiensis sp. nov., a new thermophilic anaerobic bacterium belonging to the order Thermotogales, isolated from deep-sea hydrothermal vents in the Southwestern Pacific Ocean. Int J Syst Bacteriol 47, 1118-1123.

Balch, W. E. \& Wolfe, R. S. (1976). New approach to the cultivation of methanogenic bacteria: 2-mercaptoethanesulfonic acid (HS-CoM)-dependent growth of Methanobacterium ruminantium in a pressurized atmosphere. Appl Environ Microbiol 32, 781-791.

Blöchl, E., Rachel, R., Burggraf, S., Hafenbradl, D., Jannasch, H. W. \& Stetter, K. O. (1997). Pyrolobus fumarii, gen. and sp. nov., represents a novel group of archaea, extending the upper temperature limit for life to $113^{\circ} \mathrm{C}$. Extremophiles 1, 14-21.

Brosius, J., Palmer, M. L., Kennedy, P. J. \& Noller, H. F. (1978). Complete nucleotide sequence of a 16S ribosomal RNA gene from Escherichia coli. Proc Natl Acad Sci USA 75, 4801-4805.

Burggraf, S., Olsen, G. J., Stetter, K. O. \& Woese, C. R. (1992). A phylogenetic analysis of Aquifex pyrophilus. Syst Appl Microbiol 15, 352-356

Carballeira, N. M., Reyes, M., Sostre, A., Huang, H., Verhagen, M. F. J. M. \& Adams, M. W. (1997). Unusual fatty acid compositions of the hyperthermophilic archaeon Pyrococcus furiosus and the bacterium Thermotoga maritima. $J$ Bacteriol 179 , 2766-2768.

Charbonnier, F. \& Forterre, P. (1994). Comparison of plasmid DNA topology among mesophilic and thermophilic eubacteria and archaebacteria. J Bacteriol 176, 1251-1259.

Cline, J. D. (1969). Spectrophotometric determination of hydrogen sulfide in natural waters. Limnol Oceanogr 14, 454 458.

Conn, H. J., Bartholomew, J. W. \& Jennison, M. W. (1957). Staining methods. In Manual of Microbial Methods, pp. 30-36. Edited by Society of American Bacteriologists. New York: McGraw-Hill.

De Rosa, M. \& Gambacorta, A. (1994). Archaeal lipids. In Chemical Methods in Prokaryotic Systematics, pp. 197-264. Edited by M. Goodfellow \& A. G. O'Donnell. New York: Wiley.

Doddrell, D. M., Pegg, D. T. \& Bendall, M. R. (1982). Distortionless enhancement of NMR signals by polarization transfer. J Magn Reson 48, 323-327.

Felsenstein, J. (1993). PHYLIP (phylogeny interference package), version $3.5 \mathrm{c}$. Seattle: University of Washington. 
Ferrante, G., Ekiel, I., Patel, G. B. \& Sprott, D. (1988). Structure of the major polar lipids isolated from the aceticlastic methanogen, Methanothrix concilii GP6. Biochim Biophys Acta 963, 162-172.

Galtier, N., Gouy, M. \& Gautier, C. (1996). SeaView and Phylowin, two graphic tools for sequence alignment and molecular phylogeny. Comput Appl Biosci 12, 543-548.

Harmsen, H. J. M., Prieur, D. \& Jeanthon, C. (1997a). Distribution of microorganisms in deep-sea hydrothermal vent chimneys investigated by whole-cell hybridization and enrichments of thermophilic subpopulations. Appl Environ Microbiol 63, 28762883.

Harmsen, H. J. M., Prieur, D. \& Jeanthon, C. (1997b). Groupspecific 16S rRNA-targeted oligonucleotide probes to identify thermophilic bacteria in marine hydrothermal vents. Appl Environ Microbiol 63, 4061-4068.

Hobbie, J. E., Daley, R. J. \& Jasper, S. (1977). Use of Nucleopore filters for counting bacteria by fluorescence microscopy. Appl Environ Microbiol 33, 1225-1228.

Huber, R. \& Stetter, K. O. (1992). The order Thermotogales. In The Prokaryotes, 2nd edn, pp. 3809-3815. Edited by A. Balows, H. G. Trüper, M. Dworkin, W. Harder \& K. H. Schleifer. New York: Springer.

Huber, R., Langworthy, T. A., Konig, H., Thomm, M., Woese, C. R., Sleytr, U. B. \& Stetter, K. O. (1986). Thermotoga maritima sp. nov. represents a new genus of unique extremely thermophilic eubacteria growing up to $90^{\circ} \mathrm{C}$. Arch Microbiol 144, 324-333.

Huber, R., Woese, C. R., Langworthy, T. A., Fricke, H. \& Stetter, K. O. (1989). Thermosipho africanus gen. nov. represents a new genus of thermophilic eubacteria within the 'Thermotogales'. Syst Appl Microbiol 12, 32-37.

Huber, R., Woese, C. R., Langworthy, T. A., Kristjansson, J. K. \& Stetter, K. O. (1990). Fervidobacterium islandicum sp. nov., a new extremely thermophilic eubacterium belonging to the "Thermotogales'. Arch Microbiol 154, 105-111.

Huber, R., Wilharm, T., Huber, D., Trincone, A., Burggraf, S., König, H., Rachel, R., Rockinger, I., Fricke, H. \& Stetter, K. O. (1992). Aquifex pyrophilus gen. nov., sp. nov. represents a novel group of marine hyperthermophilic hydrogen-oxidizing bacterium. Syst Appl Microbiol 15, 340-351.

Huelsenbeck, J. P. \& Hillis, D. M. (1993). Success of phylogenetic methods in the four-taxon case. Syst Biol 42, 247-264.

Ingvorsen, K. \& Jorgensen, B. B. (1979). Combined measurement of oxygen and sulfide in water samples. Limnol Oceanogr 24, 390-393.

Jannasch, H. W. (1995). Microbial interactions with hydrothermal fluids. In Seafloor Hydrothermal Systems: Physical, Chemical, Biological, and Geological Interactions (Geophysical monograph 91), pp. 273-296. Edited by S. E. Humphris, R. A. Zierenberg, L. S. Mullineaux \& R. E. Thomson. Washington, DC: American Geophysical Union.

Jannasch, H. W., Huber, R., Belkin, S. \& Stetter, K. O. (1988). Thermotoga neapolitana sp. nov. of the extremely thermophilic, eubacterial genus Thermotoga. Arch Microbiol 150, 103-104.

Jeanthon, C., Reysenbach, A. L., L'Haridon, S., Gambacorta, A., Glénat, P., Pace, N. R. \& Prieur, D. (1995). Thermotoga subterranea sp. nov., a new thermophilic bacterium isolated from a oil reservoir. Arch Microbiol 164, 91-97.

Jones, W. J., Leigh, J. A., Mayer, F., Woese, C. R. \& Wolfe, R. S. (1983). Methanococcus jannaschii, sp. nov., an extremely thermophilic methanogen from a submarine hydrothermal vent. Arch Microbiol 136, 254-261.
Jones, W. J., Stugard, C. E. \& Jannasch, H. W. (1989). Comparison of thermophilic methanogens from submarine hydrothermal vents. Arch Microbiol 151, 214-318.

Kawasumi, T., Igarashi, Y., Kodama, T. \& Minoda, Y. (1984). Hydrogenobacter thermophilus gen. nov., sp. nov., an extremely thermophilic aerobic, hydrogen-oxidizing bacterium. Int $J$ Syst Bacteriol 34, 5-10.

Kim, J. (1993). Improving the accuracy of phylogenetic estimation by combining different methods. Syst Biol 42, 331-340.

Kurr, M., Huber, R., König, H., Jannasch, H. W., Fricke, H., Trincone, A., Kristjansson, J. K. \& Stetter, K. O. (1991). Methanopyrus kandleri, gen. and sp. nov. represents a novel group of hyperthermophilic methanogens, growing at $110^{\circ} \mathrm{C}$. Arch Microbiol 156, 239-247.

Langworthy, T. A. \& Pond, J. L. (1986). Membranes and lipids of thermophiles. In Thermophiles: General, Molecular, and Applied Microbiology, pp. 107-135. Edited by T. D. Brock. New York: Wiley.

L'Haridon, S., Reysenbach, A. L., Glénat, P., Prieur, D. \& Jeanthon, C. (1995). Hot subterranean biosphere in a continental oil reservoir. Nature 377, 223-224.

Manaia, C. M., Hoste, B., Gutierrez, M. C., Gillis, M., Ventosa, A., Kersters, K. \& Da Costa, M. S. (1994). Halotolerant Thermus strains from marine and terrestrial hot springs belong to Thermus thermophilus (ex Oshima and Imahori, 1974) nom. rev. emend. Syst Appl Microbiol 17, 526-532.

Marmur, J. \& Doty, D. (1962). Determination of the base composition of deoxyribonucleic acid from its thermal denaturation temperature. $J$ Mol Biol 5, 109-118.

Marteinsson, V. T., Birrien, J.-L., Kristjansson, J. K. \& Prieur, D. (1995). First isolation of thermophilic aerobic non-sporulating heterotrophic bacteria from deep-sea hydrothermal vents. FEMS Microbiol Ecol 18, 163-174.

Marteinsson, V. T., Birrien, J.-L., Jeanthon, C. \& Prieur, D. (1996). Numerical taxonomic study of thermophilic Bacillus isolated from three geographically separated deep-sea hydrothermal vents. FEMS Microbiol Ecol 21, 255-266.

Marteinsson, V. T., Birrien, J.-L. \& Prieur, D. (1997). In situ enrichment and isolation of thermophilic microorganisms from deep-sea hydrothermal environments. Can J Microbiol $\mathbf{4 3}$, 694-697.

Olsen, G. J., Matsuda, H., Hagstrom, R. \& Overbeek, R. (1994). fastDNAml: a tool for construction of phylogenetic trees of DNA sequences using maximum likelihood. Comput Appl Biosci 10, 41-48.

Patel, B. K. C., Morgan, H. W. \& Daniel, R. M. (1985). Fervidobacterium nodosum gen. nov. and spec. nov., a new chemoorganotrophic, caldoactive, anaerobic bacterium. Arch Microbiol 141, 63-69.

Pfennig, N., Widdel, F. \& Trüper, H. G. (1981). The dissimilatory sulfate-reducing bacteria. In The Prokaryotes, 2 nd edn, pp. 926-940. Edited by M. Starr, H. Stolp, H. G. Trüper, A. Balows \& H. G. Schlegel. New York: Springer.

Pitulle, C., Yang, Y., Marchiani, M., Moore, E. R. B., Siefert, J. L., Aragno, M., Jurtshuk, P., Jr \& Fox, G. E. (1994). Phylogenetic position of the genus Hydrogenobacter. Int J Syst Bacteriol 44 , 620-626.

Prieur, D., Erauso, G. \& Jeanthon, C. (1995). Hyperthermophilic life at deep-sea hydrothermal vents. Planet Space Sci 43, 115-122.

Reysenbach, A.-L., Wickham, G. S. \& Pace, N. R. (1994). Phylogenetic analysis of the hyperthermophilic pink filament com- 
munity in Octopus Spring, Yellowstone National Park. Appl Environ Microbiol 60, 2113-2119.

Saitou, N. \& Nei, M. (1987). The neighbor-joining method: a new method for reconstructing phylogenetic trees. Mol Biol Evol 4, 406-425.

Sambrook, J., Fritch, E. F. \& Maniatis, T. (1989). Molecular Cloning : a Laboratory Manual, 2nd edn. Cold Spring Harbor, NY : Cold Spring Harbor Laboratory.

Sleytr, U. B., Messner, P. \& Pum, D. (1988). Analysis of crystalline bacterial surface layers by freeze-etching, metal-shadowing, negative staining and ultrathin sectioning. Methods Microbiol 20, 29-60.

Sleytr, U. B., Messner, P., Pum, D. \& Sára, D. (1996). Crystalline Bacterial Cell Surface Proteins. London: Academic Press.

Soriente, A., Sodano, G., Gambacorta, A. \& Trincone, A. (1992). Structure of the 'heterocyst glycolipids' of the marine cyanobacterium Nodularia harveyana. Tetrahedron 48, 5375-5384.

Stetter, K. O. (1996). Hyperthermophilic procaryotes. FEMS Microbiol Rev 18, 149-158.
Stetter, K. O., Huber, R., Blochl, E., Kurr, M., Eden, R. D., Fielder, M., Cash, H. \& Vance, I. (1993). Hyperthermophilic archaea are thriving in deep North Sea and Alaskan oil reservoirs. Nature 365, 743-745.

Widdel, F. \& Bak, F. (1992). Gram-negative mesophilic sulfatereducing bacteria. In The Prokaryotes, 2nd edn, pp. 3352-3378. Edited by A. Balows, H. G. Trüper, M. Dworkin, W. Harder \& K. H. Schleifer. New York: Springer.

Windberger, E., Huber, R., Trincone, A., Fricke, H. \& Stetter, K. O. (1989). Thermotoga thermarum sp. nov. and Thermotoga neapolitana occurring in African continental solfataric springs. Arch Microbiol 151, 506-512.

Woese, C. R. (1987). Bacterial evolution. Microbiol Rev 51, 221-271.

Woese, C. R., Kandler, O. \& Wheelis, M. L. (1990). Towards a natural system of organisms : proposal for the domain Archaea, Bacteria, and Eucarya. Proc Natl Acad Sci USA 87, 4576-4579.

Zhao, H., Wood, A. G., Widdel, F. \& Bryant, M. P. (1988). An extremely thermophilic Methanococcus from a deep-sea hydrothermal vent and its plasmid. Arch Microbiol 150, 178-183. 